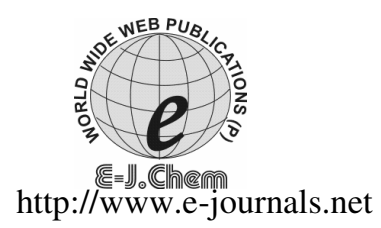

ISSN: 0973-4945; CODEN ECJHAO

E-Journal of Chemistry

$2011,8(3), 1250-1257$

\title{
Adsorption and Inhibitive Properties of Triazolo- pyrimidine Derivatives in Acid Corrosion of Mild Steel
}

\author{
K.PARAMESWARI ${ }^{*}$, S.CHITRA, S.KAVITHA, J.RAJPRIYA and A.SELVARAJ ${ }^{\S}$ \\ PSGR Krishnammal College for Women \\ Coimbatore, Tamilnadu, India \\ ${ }^{\S}$ CBM College, Coimbatore, Tamilnadu, India \\ parampps@yahoo.co.in
}

Received 16 September 2010; Revised 19 November 2010; Accepted 15 December 2010

\begin{abstract}
Inhibitive and adsorption properties of synthesized triazolopryimidine derivatives (P1, P2 \& P3 ) for the corrosion of mild steel was investigated using weight loss and electrochemical methods. Inhibition efficiency increased as the concentration of the inhibitor increased but decreased with increase in temperature. The triazolopyrimidines were found to act as adsorption inhibitors for the corrosion of mild steel. The adsorption mechanism of the triazolopyrimidine was found to be physisorption, spontaneous and exothermic. Also the adsorption followed Langmuir adsorption isotherm. polarisation studies showed that the inhibitors behave as cathodic type.
\end{abstract}

Keywords: Triazolopyrimidines, Mild steel, Adsorption, Corrosion inhibition, Polarization

\section{Introduction}

The use of inhibitors is an important method of protecting materials against corrosion. Compounds with functional group containing heteroatom which can donate lone pair of electrons are found to be particularly useful as inhibitors for corrosion of metals. Organic heterocyclic compounds containing azole nucleus have been found to be effective inhibitors for steel in different corrosive media ${ }^{1-3}$. Bentiss et $a l^{4}$ and Lagrenee $e t a l^{5}$ have studied the effect of addition of triazoles and their derivatives on the corrosion of steel in $1 \mathrm{M} \mathrm{HCl}$ and $0.5 \mathrm{M} \mathrm{H}_{2} \mathrm{SO}_{4}$. They found a high inhibition efficiency value attributed to the electron density around pyrazole nitrogen. Bellachou $e t a l^{6}$ showed that benzotriazole is an effective inhibitor for $904 \mathrm{c}$ stainless steel in phosphoric acid. Several triazole derivatives have been synthesized and tested as effective inhibitors against copper corrosion ${ }^{7-10}$. A review of literature reveal that the triazolopyrimidines have not been so far reported as inhibitors for acidic corrosion of steel or copper. Hence an attempt has been made to synthesize triazolopyrimidines and evaluate their corrosion inhibitive properties for mild steel. 


\section{Experimental}

The triazolopyrimidines have been synthesized in 3 stages by literature method ${ }^{11}$. Condensation of ethylacetoacetate with urea or thiourea in presence of benzaldehyde yielded pyrimidine derivative containing carbethoxy group. This group was then converted into its hydrazide and then condensed with diverse aromatic aldehydes to give the triazolopyrimidinones and triazolopyrimidimothiones. The structure of the compound is shown in the Figure 1.

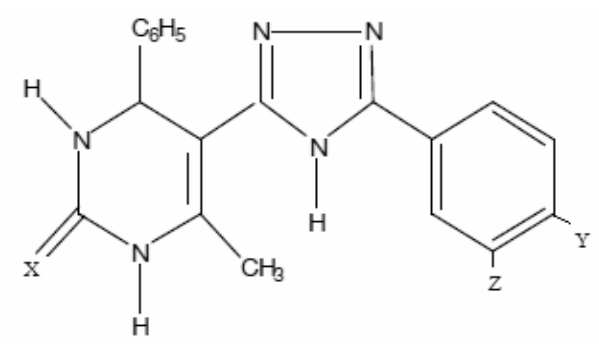

P1: $X=O ; Y=H ; Z=H, P 2: X=S ; Y=H ; Z=H, P 3: X=O ; Y=O H ; Z=O_{3}$

Figure 1. Structure of the inhibitors

The weight percentage composition of mild steel used was Mn $0.36 \%$, P $0.25 \%$, C $0.084 \%$, Si $0.12 \%$ and the remainder iron. Mild steel coupons with double side surface area $19.9285 \mathrm{~cm}^{2}$ was used for weight loss measurements, while for the polarization experiments a cylindrical rod embedded in teflon with an exposed area of $0.785 \mathrm{~cm}^{2}$ was used. Before each experiment the electrodes were polished with different grade emery papers, degreased with acetone rinsed under running water and finally dried.

\section{Weight loss method}

The polished and pre-weighed mild steel specimen were carefully hanged in hooks and suspended in $100 \mathrm{~mL}$ test solutions with and without inhibitors of different concentration at $303 \mathrm{~K}$. The temperature was controlled by an aqueous thermostat.

After $3 \mathrm{~h}$ of immersion in the corrodent solution, the specimen was carefully washed in double distilled water dried and then weighed. The percentage of inhibition efficiency (IE\%) for various concentrations of the inhibitors were calculated as

Inhibition efficiency, $\%=\frac{\text { (weight loss without inhibitor)- (weight loss with inhibitor) }}{\text { weight loss without inhibitor }} \times 100$

The effect of temperature on the inhibitiory action of the inhibitos was determined by weight loss method at various concentratons at different temperature $(313,323 \& 333 \mathrm{~K})$ for a fixed immersion time of $1 \mathrm{~h}$.

\section{Polarisation and impedance studies}

Electrochemical studies were carried out using the potentiostat model 1280 B solartron (U.K). Electrochemical measurements were carried out in a glass cell with a capacity of $100 \mathrm{~mL}$. A platinum electrode and a saturated calomel electrode (SCE) were used as counter electrode and reference electrode respectively.

The polarisation measurements were carried out with a scan rate of $1 \mathrm{mV} / \mathrm{Sec}$ in the range of $-200 \mathrm{mV}$ to $+200 \mathrm{mV} v s$. corrosion potential of the working electrode measured against SCE. The AC impedence measurements are shown as Nyquist plots and polarisation 
data as Tafel plots. The impedence measurements were made at a corrosion potentials with the Ac voltage amplitude $10 \mathrm{mV}$ in the frequency range $10 \mathrm{KHz}$ to $0.01 \mathrm{KHz}$. The $\mathrm{I}_{\text {corr }}, \mathrm{E}_{\text {corr }}, \mathrm{R}_{\mathrm{t}}$ and $\mathrm{C}_{\mathrm{dl}}$ values were obtained from the data using the corresponding "corr view" and " $\mathrm{Z}$ view" softwares.

\section{Results and Discussion}

Weight loss studies

The rate of corrosion of mild steel in $\mathrm{H}_{2} \mathrm{SO}_{4}$ decreased with increase in concentration of the inhibitor and inhibition efficiency increases with concentration of the compounds (Table 1) which may be explained as follows. An increase in the inhibitor concentration increases the surface coverage and more number of molecules gets adsorbed over the mild steel surface blocking the active sites of acid attack and thereby protecting the metal from corrosion.

Table 1. Inhibition efficiency (\%) of the inhibitors and corrosion rate (mpy) of mild steel in $1 \mathrm{M} \mathrm{H}_{2} \mathrm{SO}_{4}$ obtained by weight loss method at $303 \mathrm{~K}$

\begin{tabular}{|c|c|c|c|c|c|c|}
\hline \multirow{2}{*}{$\begin{array}{c}\text { Conc of } \\
\text { Inhibitors } \\
\mathrm{mM}\end{array}$} & \multicolumn{2}{|c|}{ P1 } & \multicolumn{2}{|c|}{$\mathrm{P} 2$} & \multicolumn{2}{|c|}{ P3 } \\
\hline & I.E\% & $\begin{array}{c}\text { Corr rate, } \\
\text { mpy }\end{array}$ & I.E\% & $\begin{array}{c}\text { Corr rate, } \\
\text { mpy }\end{array}$ & I.E\% & $\begin{array}{c}\text { Corr rate, } \\
\text { mpy }\end{array}$ \\
\hline Blank & - & 3835.2 & - & 3835.2 & - & 3835.2 \\
\hline 0.02 & 50.08 & 1886.5 & 66.39 & 1288.79 & 51.09 & 1875.9 \\
\hline 0.04 & 65.94 & 1306.2 & 82.29 & 656.91 & 68.18 & 1222.7 \\
\hline 0.06 & 73.77 & 1005.8 & 89.18 & 414.93 & 75.44 & 942.13 \\
\hline 0.08 & 76.86 & 888.75 & 96.22 & 144.88 & 80.91 & 732.01 \\
\hline 0.1 & 80.02 & 766.1 & 98.75 & 47.78 & 82.29 & 678.71 \\
\hline 0.15 & 83.31 & 640.2 & 99.15 & 32.61 & 86.69 & 511.26 \\
\hline 0.25 & 87.40 & 483.2 & 99.16 & 31.85 & 89.92 & 383.83 \\
\hline 0.5 & 93.81 & 237.4 & 99.43 & 21.99 & 92.62 & 282.94 \\
\hline 1 & 96 & 150.9 & 99.72 & 10.65 & 93.79 & 238.18 \\
\hline
\end{tabular}

Table 2 reveals that the rate of corrosion of mild steel increases with increase in temperature in the presence and absence of the inhibitors. Relatively lower rate of corrosion is observed in the presence of inhibitors. The decrease in the rate of corrosion, being more predominant in the case of triazolopyrimidine thiones.

Table 2. Inhibition efficiency (\%) of $1 \mathrm{mM}$ concentration of inhibitors and corrosion rate of mild steel in corrosion in $1 \mathrm{M} \mathrm{H}_{2} \mathrm{SO}_{4}$ at different temperature

\begin{tabular}{ccccccc}
\hline \multirow{2}{*}{$\begin{array}{c}\text { Temperature, } \\
\text { K }\end{array}$} & I.E\% & $\begin{array}{c}\text { Corr rate, } \\
\text { mpy }\end{array}$ & I.E\% & $\begin{array}{c}\text { Corr rate, } \\
\text { mpy }\end{array}$ & I.E\% & $\begin{array}{c}\text { Corr rate, } \\
\text { mpy }\end{array}$ \\
\cline { 2 - 7 } 303 & 96.00 & 452.86 & 99.72 & 31.85 & 93.79 & 304.94 \\
313 & 90.32 & 666.77 & 99.54 & 50.06 & 90.72 & 639.46 \\
323 & 85.48 & 1606.63 & 98.91 & 75.09 & 84.35 & 1731.79 \\
333 & 79.54 & 2424.03 & 88.41 & 113.66 & 62.51 & 6895.3 \\
\hline
\end{tabular}

Thermodynamic parameters

The activation energy $E_{a}$ at different concentration of the inhibitor in $1 \mathrm{M} \mathrm{H}_{2} \mathrm{SO}_{4}$ was calculated by plotting logarithms of corrosion rate vs. 1/T (Figure 2). The slope of the line multiplied by the ideal gas constant $R$ gives the activation energy $E_{a}$ (Table 3 ). The values for the inhibitors are higher than that of the blank acid value indicating that the inhibitors act by physisorption mechanism ${ }^{12}$. Thermodynamic parameters, such as the change in enthalpy $\left(\Delta \mathrm{H}^{*}\right)$ and entropy $\left(\Delta \mathrm{S}^{*}\right)$ of activated state can be determined according to the following equation .

Corrosion rate $=\mathrm{RT} / \mathrm{Nh} \exp \left(\Delta \mathrm{S}^{*} / \mathrm{R}\right) \exp \left(-\Delta \mathrm{H}^{*} / \mathrm{R}\right)$ 


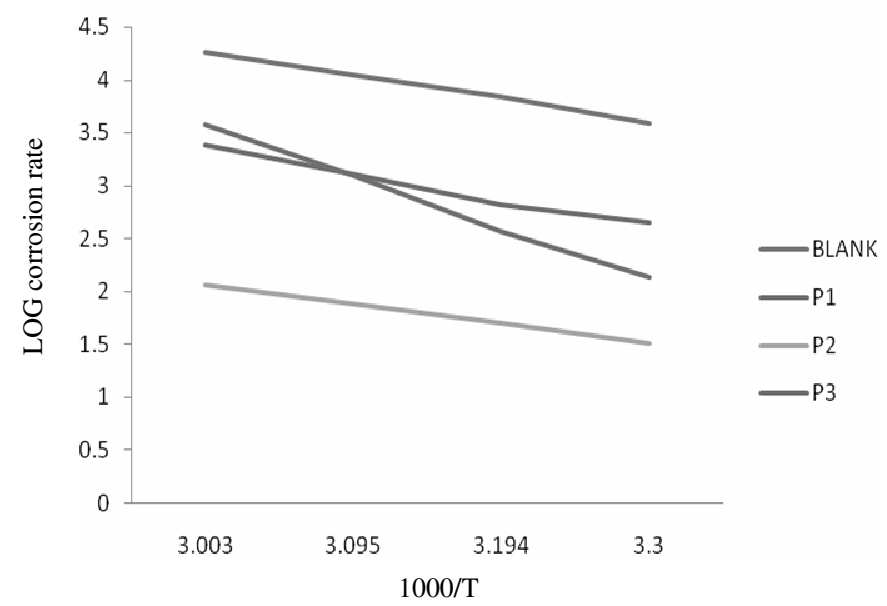

Figure 2. Arrhenius plots of corrosion rate of mild steel in $1 \mathrm{M} \mathrm{H}_{2} \mathrm{SO}_{4}$ solution in the presence and absence of inhibitors

Table 3. Thermodynamic parameters for mild steel corrosion in $1 \mathrm{M} \mathrm{H}_{2} \mathrm{SO}_{4}$ in the presence and absence of inhibitors at $1 \mathrm{mM}$ concentration

\begin{tabular}{cccccccc}
\hline Name of the & $-\Delta \mathrm{H}^{\circ}$, & $-\Delta \mathrm{S}^{\circ}$, & & \multicolumn{4}{c}{$\Delta \mathrm{G}_{\text {ads }}$ at various temperatures $(\mathrm{kJ})$} \\
\cline { 5 - 8 } inhibitor & $\mathrm{kJ} / \mathrm{mole}$ & $\mathrm{J} \mathrm{K}^{-1}$ mole & $\mathrm{E}_{\mathrm{a}}, \mathrm{kJ}$ & $303 \mathrm{~K}$ & $313 \mathrm{~K}$ & $323 \mathrm{~K}$ & $333 \mathrm{~K}$ \\
\hline Blank & 0.01887 & 0.10542 & 43.46 & - & - & - & - \\
P1 & 0.05004 & 0.04107 & 65.75 & -18.16 & -15.73 & -14.56 & -23.66 \\
P2 & 0.08929 & +0.08363 & 113.48 & -24.92 & $-21,46$ & -23.66 & -8.92 \\
P3 & 0.03915 & 0.06958 & 52.82 & -16.95 & -15.86 & -14.36 & -11.40 \\
\hline
\end{tabular}

The negative value of $\Delta \mathrm{G}^{*}$ indicates spontaneous adsorption of the inhibitors. But the values are within $-20 \mathrm{KJ} / \mathrm{mol}$, which are consistent with the electrostatic interaction between the charged inhibitors molecules and charged metal.

$\Delta \mathrm{S}^{*}$ values are less negative or positive in the presence of the pyrimidines as compared to that of the blank acid, which shows that there is more disorder in the presence of inhibitors, which may be attributed to desorption of the molecules from the mild steel surface leading to randomness. The values for thiones are positive. Therefore reaction is irreversible i.e. complete desorption is not possible. The more negative values of $\Delta \mathrm{H}^{*}$ indicate that the adsorption of inhibitor molecules is exothermic which implies that IE decreases with temperature.

\section{Adsorption isotherm}

The most frequently used adsorption isotherms are Langmuir, Tempkin, Freundlich, Frumkin, Flory-Huggins, Bockris-Swinkel and El-Awady. The surface coverage values $(\theta)$ obtained from weight loss studies at $30 \pm 1{ }^{\circ} \mathrm{C}$ for various concentration were tested graphically for fitting a suitable adsorption isotherm. The plot of $\mathrm{C} / \theta$ vs. C yielded a straight line (Figure 3) This observation clearly proves that the adsorption of pyrimidines from $1 \mathrm{M} \mathrm{H}_{2} \mathrm{SO}_{4}$ solutions. on the mild steel surface obeys the Langmuir adsorption isotherm. The expected linear relationship is approximated from the correlation co efficient $\mathrm{R}^{2}$ equal to $\sim 0.99$ and the slope $\sim 0.95$. The deviation of the slope from unity is interpreted as a sign that the adsorbing species occupy more or less a typical adsorption site at the metal- solution interface ${ }^{13}$. 


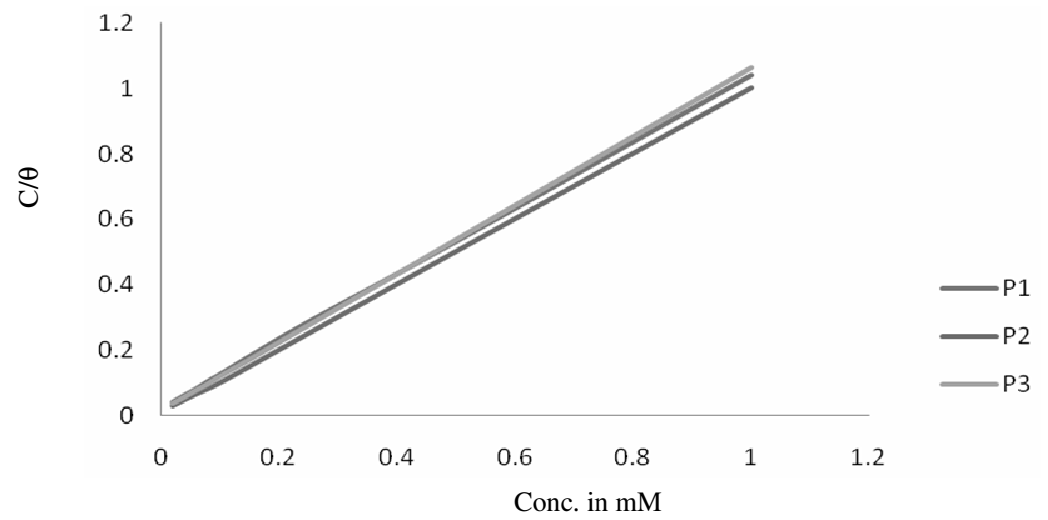

Figure 3. Langmuir plot of inhibitors for mild steel in $1 \mathrm{M} \mathrm{H}_{2} \mathrm{SO}_{4}$

\section{Electrochemical studies}

Potentiodynamic polarization curves for mild steel in $1 \mathrm{M} \mathrm{H}_{2} \mathrm{SO}_{4}$ in presence of $\mathrm{P} 1$ are shown in Figure 4 . The polarization parameters $E_{\text {corr }}$, Tafel slopes $\left(b_{a}, b_{c}\right), I_{\text {corr }}$ and inhibition efficiency are given in Table 4 . The $\mathrm{E}_{\text {corr }}$ value is shifted slightly in the positive direction for $\mathrm{P} 2$ and slightly negative direction for P1 and P3. The presence of pyrimidines led to a variation in the value of Tafel slopes but more shift in the cathodic slopes. Therefore the mechanism of inhibition is under cathodic control. The cathodic hydrogen evolution reaction was polarized to the maximum extent leading to inhibition. $I_{\text {corr }}$ value decreases and inhibition efficiency increases with concentration of inhibitors.

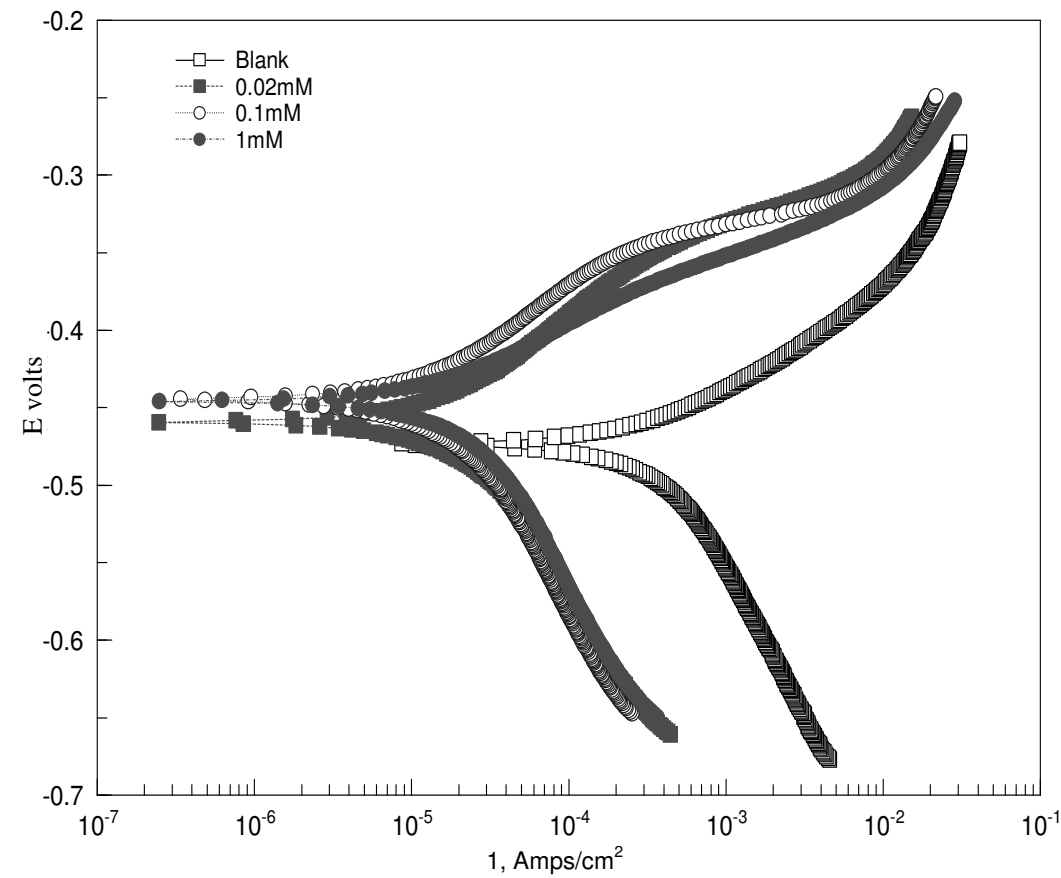

Figure 4. Polarization curves for mild steel recorded in $1 \mathrm{M} \mathrm{H}_{2} \mathrm{SO}_{4}$ for selected concentrations of inhibitor (P1) 
Table 4. Polarization parameters for mild steel in $1 \mathrm{M} \mathrm{H}_{2} \mathrm{SO}_{4}$ solution with different concentration of the inhibitors

\begin{tabular}{|c|c|c|c|c|c|c|}
\hline \multirow{2}{*}{$\begin{array}{l}\text { Name of } \\
\text { the } \\
\text { inhibitor }\end{array}$} & \multirow{2}{*}{$\begin{array}{c}\text { Inhibitor } \\
\text { concentration, } \\
\mathrm{mM}\end{array}$} & \multicolumn{2}{|c|}{$\begin{array}{c}\text { Tafel slopes, } \\
\text { mv/dec }\end{array}$} & \multirow{2}{*}{$\begin{array}{l}\mathrm{E}_{\text {corr }} \\
\mathrm{mV}\end{array}$} & \multirow{2}{*}{$\begin{array}{c}\mathrm{I}_{\text {corr }}, \\
\mu \mathrm{Amp} / \mathrm{cm}^{2}\end{array}$} & \multirow{2}{*}{$\begin{array}{c}\text { Inhibition } \\
\text { efficiency, } \\
\%\end{array}$} \\
\hline & & $b_{a}$ & $b_{c}$ & & & \\
\hline \multirow{5}{*}{ P1 } & Blank & 80.87 & 126.3 & -474.04 & 621.78 & - \\
\hline & 0.02 & 52.95 & 137.06 & -486.03 & 17.817 & 97.13 \\
\hline & 0.1 & 84.23 & 173.36 & -483.67 & 12.992 & 97.91 \\
\hline & 1 & 114.86 & 172.02 & -489.2 & 9.3885 & 98.49 \\
\hline & 0.02 & 63.181 & 222.45 & -460.57 & 40.518 & 93.48 \\
\hline \multirow{3}{*}{ P2 } & 0.1 & 71.7 & 169.84 & -459.26 & 40.366 & 93.50 \\
\hline & 1 & 70.94 & 154.96 & -458.75 & 40.056 & 93.55 \\
\hline & 0.02 & 67.074 & 157.41 & -492.72 & 65.691 & 89.43 \\
\hline \multirow[t]{2}{*}{ P3 } & 0.1 & 68.929 & 149.33 & -498.87 & 37.172 & 94.02 \\
\hline & 1 & 71.065 & 164.8 & -490.78 & 3.5494 & 99.42 \\
\hline
\end{tabular}

Electrochemical impedance measurements were carried out over the frequency range from $10 \mathrm{KHz}$ to $0.01 \mathrm{KHz}$. The Nyquist diagram for mild steel in $1 \mathrm{M} \mathrm{H}_{2} \mathrm{SO}_{4}$ in the presence of various concentration of $\mathrm{P} 1$ is shown in Figure 5. The addition of the inhibitors increases the value of $R_{t}$ and reduces the $C_{d l}$ (Table 5). The decrease in $C_{d l}$ is attributed to an increase in thickness of the electrical double layer. The increase in the $R_{t}$ value is attributed to the formation of a protection film on the metal-solution interface ${ }^{14}$.

\section{Effect of chemical structure on corrosion inhibition}

Analysis of the inhibition efficiency values obtained by all the 3 methods, show that the triazolopyrimidine thione $\mathrm{P} 2$ is excellent inhibitor compared to pyrimidinones. The presence of sulphur atom in the thione enhances the efficiency as compared to the oxygen analog.

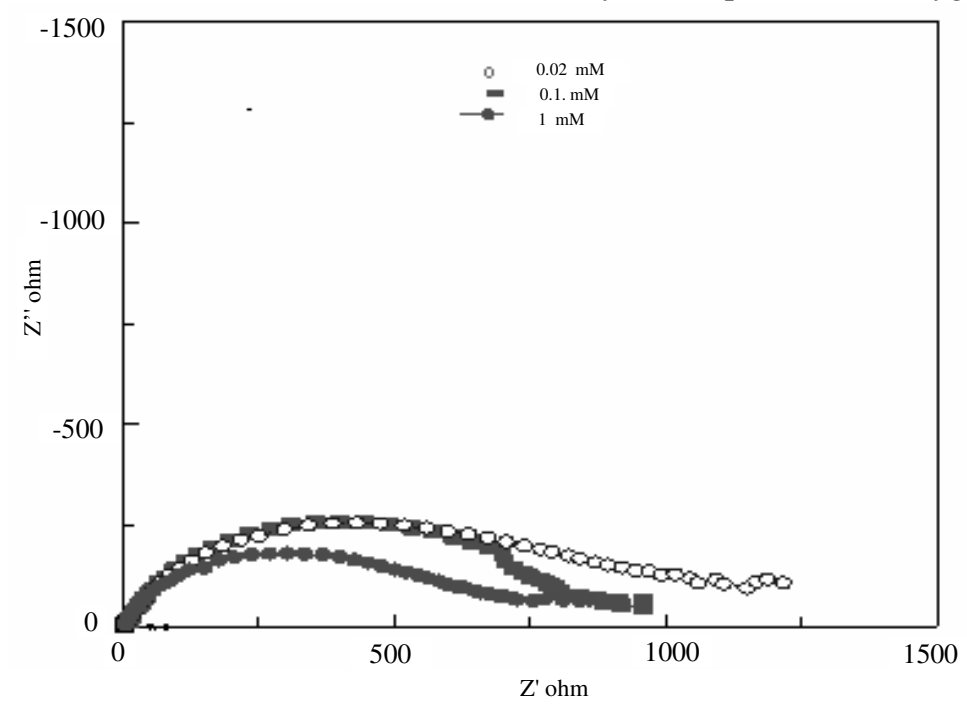

Figure 5. Nyquist diagram for mild steel in $1 \mathrm{M} \mathrm{H}_{2} \mathrm{SO}_{4}$ for selected concentrations of inhibitor $(\mathrm{P} 1)$ 
Table 5. Impedance parameters for mild steel in $1 \mathrm{M} \mathrm{H}_{2} \mathrm{SO}_{4}$ solution with different concentrations of the inhibitors

\begin{tabular}{ccccc}
\hline $\begin{array}{c}\text { Name of the } \\
\text { inhibitor }\end{array}$ & $\begin{array}{c}\text { Inhibitor } \\
\text { concentration, } 1 \mathrm{mM}\end{array}$ & $\begin{array}{c}\mathrm{R}_{\mathrm{t}}, \\
\mathrm{ohmcm}^{2}\end{array}$ & $\mathrm{C}_{\mathrm{dl}}, \mu \mathrm{F} / \mathrm{cm}^{2} \times 10^{-6}$ & $\begin{array}{c}\text { Inhibition } \\
\text { efficiency, \% }\end{array}$ \\
\hline P1 & $\begin{array}{c}\text { Blank } \\
\text { O.02 }\end{array}$ & $\begin{array}{c}10.5299 \\
699.35\end{array}$ & 34.2381 & - \\
& 0.1 & 851.09 & 4.8252 & 98.49 \\
& 1 & 1040.1 & 2.9897 & 98.76 \\
P2 & 0.02 & 293.69 & 9.2125 & 98.98 \\
& 0.1 & 328.94 & 6.3429 & 96.41 \\
& 1 & 1211.1 & 2.0684 & 99.13 \\
P3 & 0.02 & 374.98 & 8.6819 & 97.19 \\
& 0.1 & 415.63 & 6.5795 & 97.46 \\
\hline
\end{tabular}

In acid solution, the compounds containing - $\mathrm{NH}$ groups exist as protonated species, which are not likely to be adsorbed on the positively charged steel surface. The very high IE of the sulphur compound can be explained in the light of adsorption on the anodic sites through the sulphur atom. This explanation is supported by the relatively positive shift of $\mathrm{E}_{\text {corr }}$ values obtained in the presence of sulphur compounds. The result is in accordance with the findings of morad for the high inhibition efficiency of $N$-acetylcystein and $S$-benzylcystein ${ }^{15}$.

Among the pyrimidinones $\mathrm{P} 1$ and $\mathrm{P} 3$, the order of inhibition efficiency is $\mathrm{P} 1>\mathrm{P} 3$

Variation in structure of the inhibitor molecules (P1 and P3) occurs in the substituent of phenyl ring attached to triazole moiety. It may be inferred that the inhibition efficiency depends on this phenyl ring also.

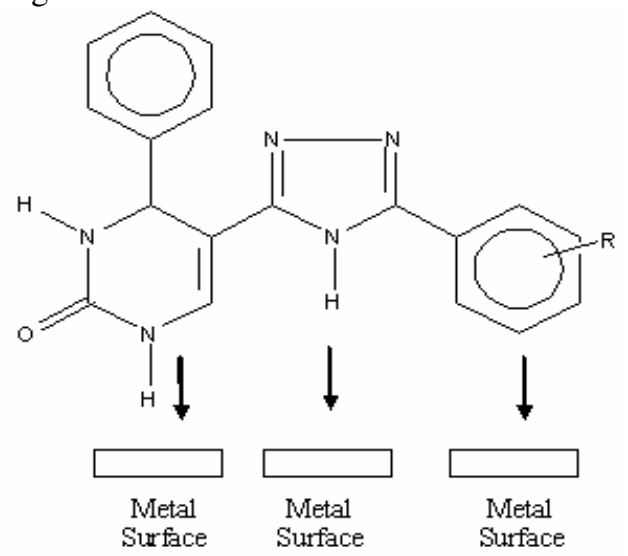

In compound $\mathrm{P} 1$, the planarity and rich $\mathrm{p}$ electrons of phenyl ring makes an additional contribution to the interaction process as Lewis base with mild steel surface. In P3 the electron donating $-\mathrm{OCH}_{3}$ and $\mathrm{OH}$ groups should give significant more basic properties and hence a higher IE. But it shows somewhat lower IE value ( $93 \%$ by weight loss method). This is because the presence of $-\mathrm{OCH}_{3}$ and $-\mathrm{OH}$ groups disturbs the planarity of the molecule and hence the phenyl ring is out of the plane of the mild steel surface.

Hence steric factor is responsible for lowering the inhibition efficiency of P3. Similar explanation was reported by Wahyuningram et al. ${ }^{16}$ for the lower inhibition efficiency of methoxy substituted phenyl-1-vinyl-1H-imidazole. 


\section{Conclusion}

The synthesized triazolopyrimidinones and triazolopyrimidinethione are good inhibitors for the corrosion of mild steel in $1 \mathrm{M} \mathrm{H}_{2} \mathrm{SO}_{4}$. Pyrimidine thione showed greater IE than pyrimidinones. The inhibition efficiency increases with concentration of inhibitor and decreases with the rise of temperature. Adsorption of the inhibitor on mild steel surface is exothermic and spontaneous and obeys Langmuir adsorption isotherm. Polarization studies reveal that the inhibitors are mixed type but slightly cathodic.

\section{References}

1. Zucchi F, Grassi V, Monticelli C and Trabanelli G, Corros Sci., 2006, 48, 522.

2. Bekkouch K, Aouniti A, Hammouti B and Kertit S, Corros Sci., 2003, 45, 1619-1630.

3. Refaey S A M, Taha F and Abd.El-Malak A M, Appl Surf Sci., 2004, 236, 175.

4. Bentiss F, Traisnel M, Lagrenee M and Hornez J C, Corros Sci., 2001, 43, 2229-2238.

5. Bouanis.M, Corros Sci., 2002, 44(3), 57.

6. Bellaouchou A, Kabkab B, Guenbour A and BenBachir A, Proc Org Coat., 2001, 41, 121-127.

7. $\quad$ Ramesh S and Rajeswari S, Corros Sci., 2005, 47(1), 151-169.

8. El-Sayed, Sherif M, Erasmus R M and Comins J D, J Colloid Int Sci, 2007, 311, 144.

9. Lalitha A, Ramesh S and Rajeswari S, Electrochimica Acta, 2005, 51, 47.

10. El-Nagger M M, Corros Sci., 2000, 42, 773-784.

11. Padhy A K, Bardhan M and Panda C S, Indian J Chem., 2003, 42B, 910-915.

12. Ebenso E E, Hailemichael Alemu, Umoren S A and Obot I B, Int J Electrochem Sci., 2008, 3, 1325-1339.

13. Tavakoli H, Shahrabi T and Hosseini M G, Mater Chem Phys., 2008, 109(2-3), 281-286.

14. Bouklah M, Ouassini A, Hammouti B and Idrissi A-El, Appl Surf Sci., 2006, 252, 2178-2185.

15. Morad M S, J Appl Electrochem, 2007, 37, 661.

16. Deana Wahyuningrum, Sadijah Achmad, Yama Maolana Syah, Buchari, Bunbun Bundijali and Bambang Ariwahjoedi, Int J Electrochem Sci., 2008, 3, 154-166. 


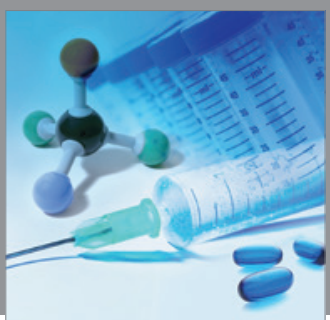

International Journal of

Medicinal Chemistry

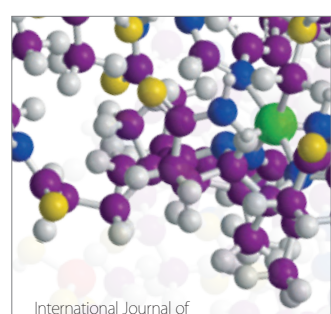

Carbohydrate Chemistry

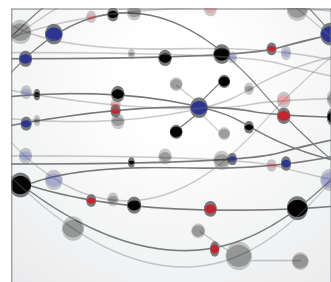

The Scientific World Journal
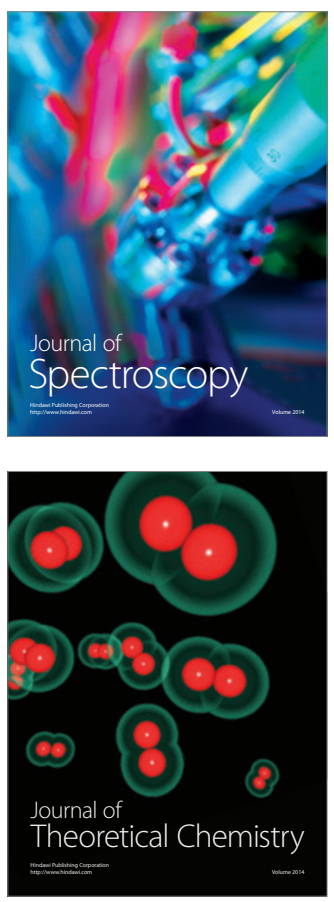
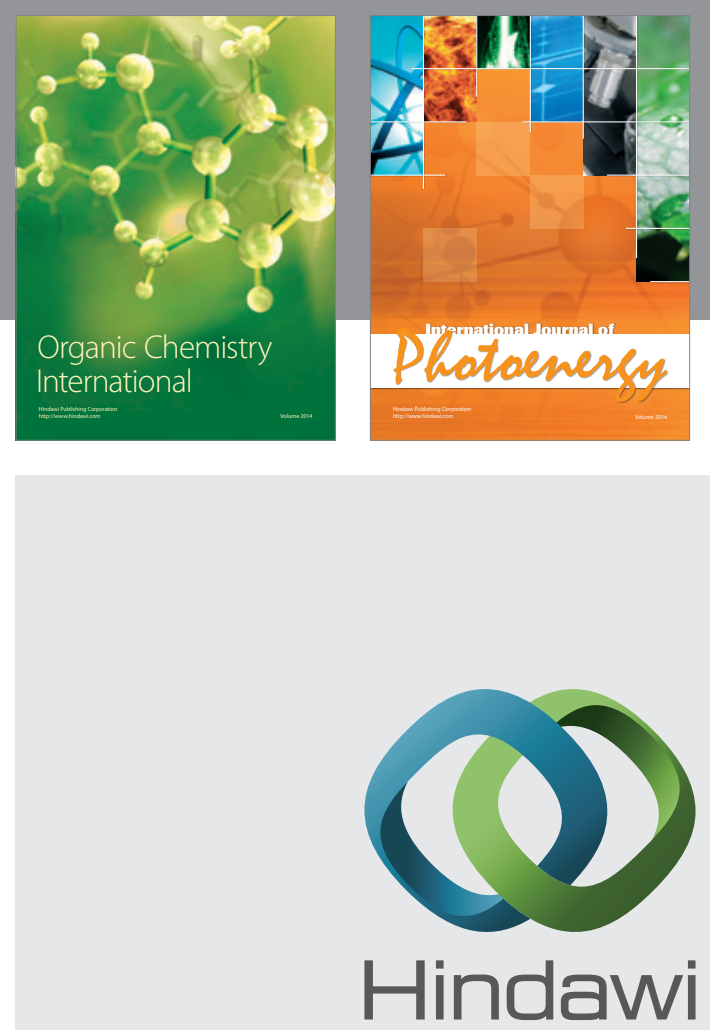

Submit your manuscripts at

http://www.hindawi.com
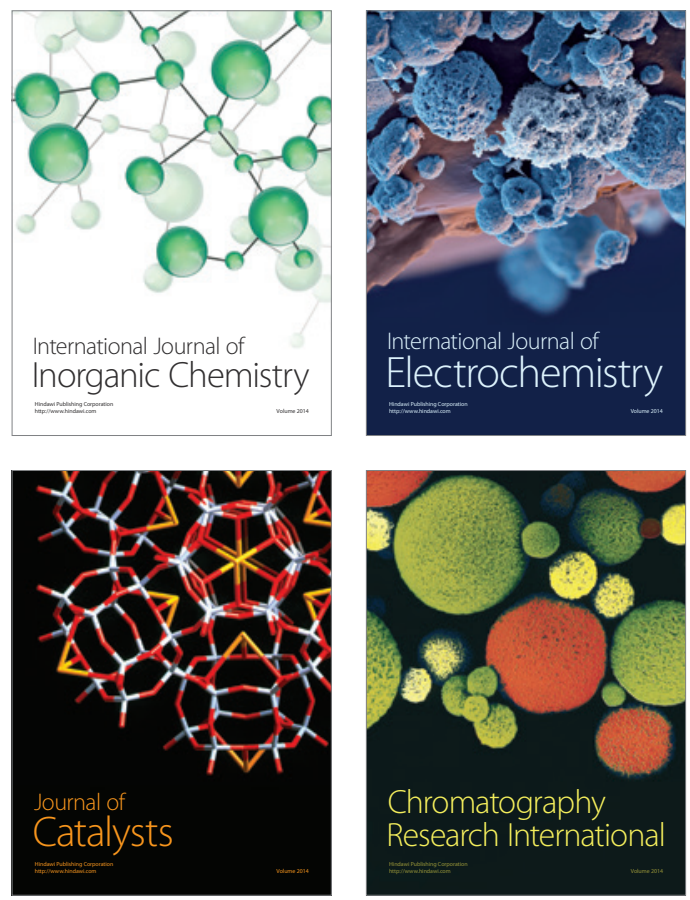
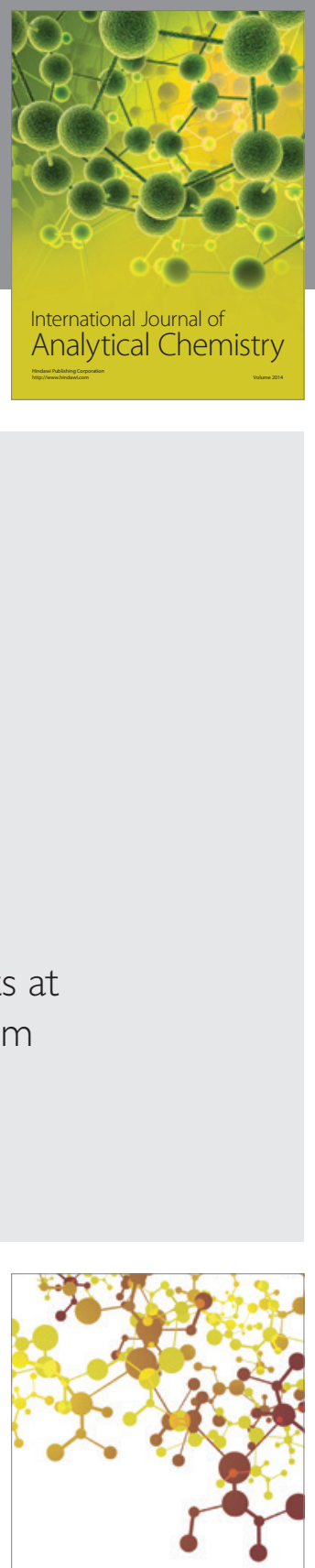

Journal of

Applied Chemistry
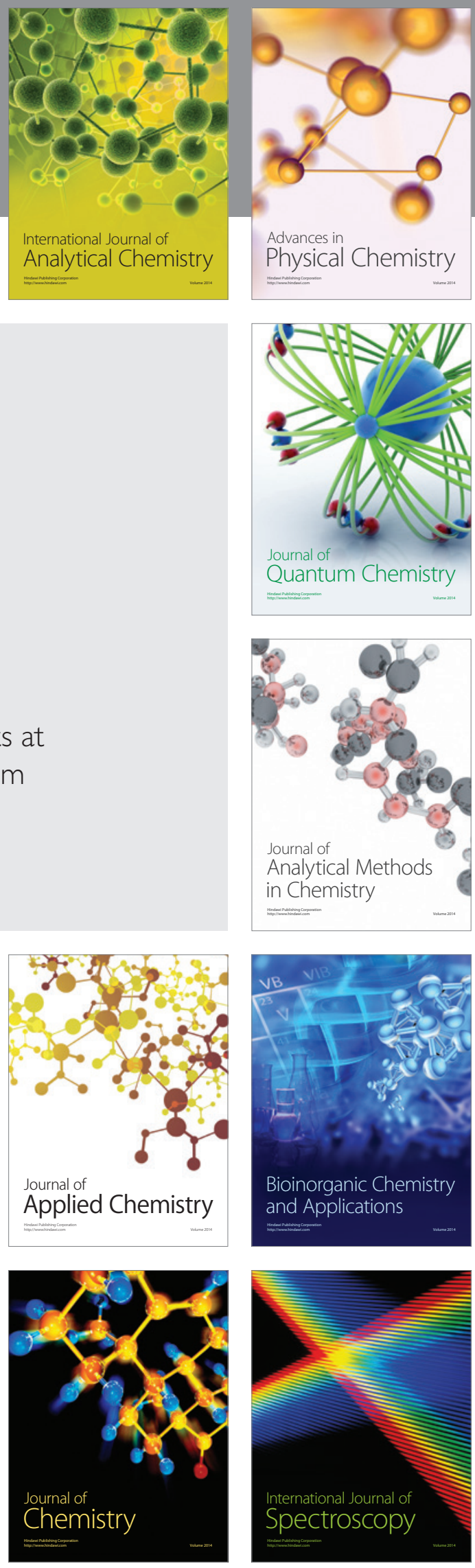